\title{
Predation of bat (Molossus molossus: Molossidae) by the centipede Scolopendra viridicornis (Scolopendridae) in Southern Amazonia
}

\author{
Janaina da Costa de NORONHA ${ }^{1,2 *}$, Leandro Dênis BATTIROLA ${ }^{1,3}$, Amazonas CHAGAS JÚNIOR ${ }^{4}$, \\ Robson Moreira de MIRANDA ${ }^{1}$, Rainiellen de Sá CARPANEDO ${ }^{1}$, Domingos de Jesus RODRIGUES ${ }^{1,2,3}$ \\ 1 Universidade Federal de Mato Grosso Campus Sinop, Acervo Biológico da Amazônia Meridional, Av. Alexandre Ferronato, nº 1200, Setor Industrial, CEP: 78557-267, Sinop, Mato \\ Grosso, Brasil. \\ 2 Universidade Federal de Mato Grosso Campus Cuiabá, Programa de Pós-Graduação em Ecologia e Conservação da Biodiversidade, Av. Fernando Corrêa da Costa, nº 2367, Bairro \\ Boa Esperança, CEP: 78060-900, Cuiabá, Mato Grosso, Brasil. \\ ${ }^{3}$ Universidade Federal de Mato Grosso Campus Sinop, Programa de Pós-Graduação em Ciências Ambientais, Av. Alexandre Ferronato, no 1200, Setor Industrial, CEP: 78557-267, \\ Sinop, Mato Grosso, Brasil. \\ ${ }^{4}$ Universidade Federal de Mato Grosso Campus Cuiabá, Av. Fernando Corrêa da Costa, nº 2367, Bairro Boa Esperança, CEP: 78060-900, Cuiabá, Mato Grosso, Brasil. \\ * Corresponding author: janainanoronha08@gmail.com
}

\section{ABSTRACT}

Centipedes are opportunistic carnivore predators, and large species can feed on a wide variety of vertebrates, including bats. The aim of this study was to report the third record of bat predation by centipedes worldwide, the first record in the Amazon region, while covering aspects of foraging, capture and handling of prey. We observed the occurence in a fortuitous encounter at Cristalino State Park, located in the Amazon region of the state of Mato Grosso, Brazil. The attack took place in a small wooden structure, at about three meters from the floor, and was observed for 20 minutes. During the observation, the centipede stung the neck and abdominal region of the bat several times, grabbing the prey with its 15 pairs of front legs while hanging from the ceiling with its hind legs. This type of observation suggests that vertebrates can be important preys for invertebrates such as giant centipedes, both for its nutritional composition and for the amount of energy available in a single prey.

KEYWORDS: Chilopoda; Chiroptera; feeding behavior.

\section{Predação de morcego (Molossus molossus: Molossidae) pela centopeia Scolopendra viridicornis (Scolopendridae) no sul da Amazônia}

\section{RESUMO}

Centopeias são predadores carnívoros oportunistas e grandes espécies podem se alimentar de uma grande variedade de vertebrados, inclusive de morcegos. O objetivo desse trabalho é reportar o terceiro registro de predaçáo de morcego por centopeia, e o primeiro para a região Amazônica, abrangendo aspectos do forrageamento, captura e manipulação da presa. $\mathrm{O}$ registro foi realizado de forma fortuita, no Parque Estadual do Cristalino, região de Floresta Amazônica, no estado de Mato Grosso, Brasil. $\mathrm{O}$ ataque ocorreu em uma estrutura de madeira a cerca de três metros de altura e foi observado por 20 minutos. Durante a observação, a centopeia picou várias vezes o pescoço e região abdominal do morcego, agarrando a presa com seus 15 pares de pernas anteriores e se pendurando ao teto com as pernas posteriores. Esse tipo de observação sugere que vertebrados podem ser importantes presas para invertebrados, como centopeias gigantes, tanto por sua composição nutricional quanto pela quantidade de energia disponível em uma única presa.

PALAVRAS-CHAVE: Chilopoda; Chiroptera; comportamento alimentar. 
Invertebrates are an important component of the food web, serving as prey for many vertebrate groups (McCormick and Polis 1982; Johnson and Triplehorn 2004; Menin et al. 2005). However, arthropods also produce substantial mortality in some vertebrate populations (McCormick and Polis 1982), and have shown to maintain complex interspecific interactions with vertebrates (Menin et al. 2005). There are few records of invertebrate predation of vertebrates (Timm and Losilla 2007; Srbek-Araujo et al. 2012), but large species of arachnids, insects and chilopods are voracious predators, and recorded diets include small vertebrates such as frogs, lizards and bats (McCormick and Polis 1982; Toledo 2005; Timm and Losilla 2007).

Centipedes are terrestrial, opportunistic, voracious and carnivorous (Dugon and Arthur 2012a,b). Predation is achieved with a pair of modified legs (forcipules) located ventrally and preceding the head and mouth. Venom from a gland at the forcipule base kills prey via injection (Malta et al. 2008; Dugon and Arthur 2012a,b). Centipedes are thought to feed predominantly on prey alive (Voigtländer 2011), which are generally seized with the anterior legs then envenimated via a stabbing motion of the forcipules (Dugon and Arthur 2012b). There are records of them killing several types of animals, such as frogs, snakes and bats (McCormick and Polis 1982; Forti et al. 2007; Srbek-Araujo et al. 2012).

Despite the fact that giant centipedes (Scolopendridae) are voracious predators, there are only two records of bat predation by scolopendrid centipedes: one in a cave in a thorn scrub region in Venezuela (Molinari et al. 2005) and another in the roof of a house in the Atlantic Forest, located in northern Espírito Santo State, southeastern Brazil (Srbek-Araujo et al. 2012). These two records comment on the body part consumed, but they do not describe the foraging behavior of the scolopendrid centipedes involved. The purpose of this study was to report the third record of bat predation by centipedes worldwide, the first record in the Amazon region, while covering aspects of foraging, capture and handling of prey.

The event occurred at Cristalino State Park $\left(055^{\circ} 49^{\prime} \mathrm{W}\right.$; $09^{\circ} 27^{\prime}$ 'S, Figure 1), a 180.000 ha public-access protected area located in northern Mato Grosso state, central Brazil. The reserve is located in the southern part of the Amazonian Biome. Phytogeographically, forest at Cristalino State Park is classified as a Semi-deciduous Seasonal Forest. Following the Köppen (1936) classification, the climate is Am (tropical moonsonal),

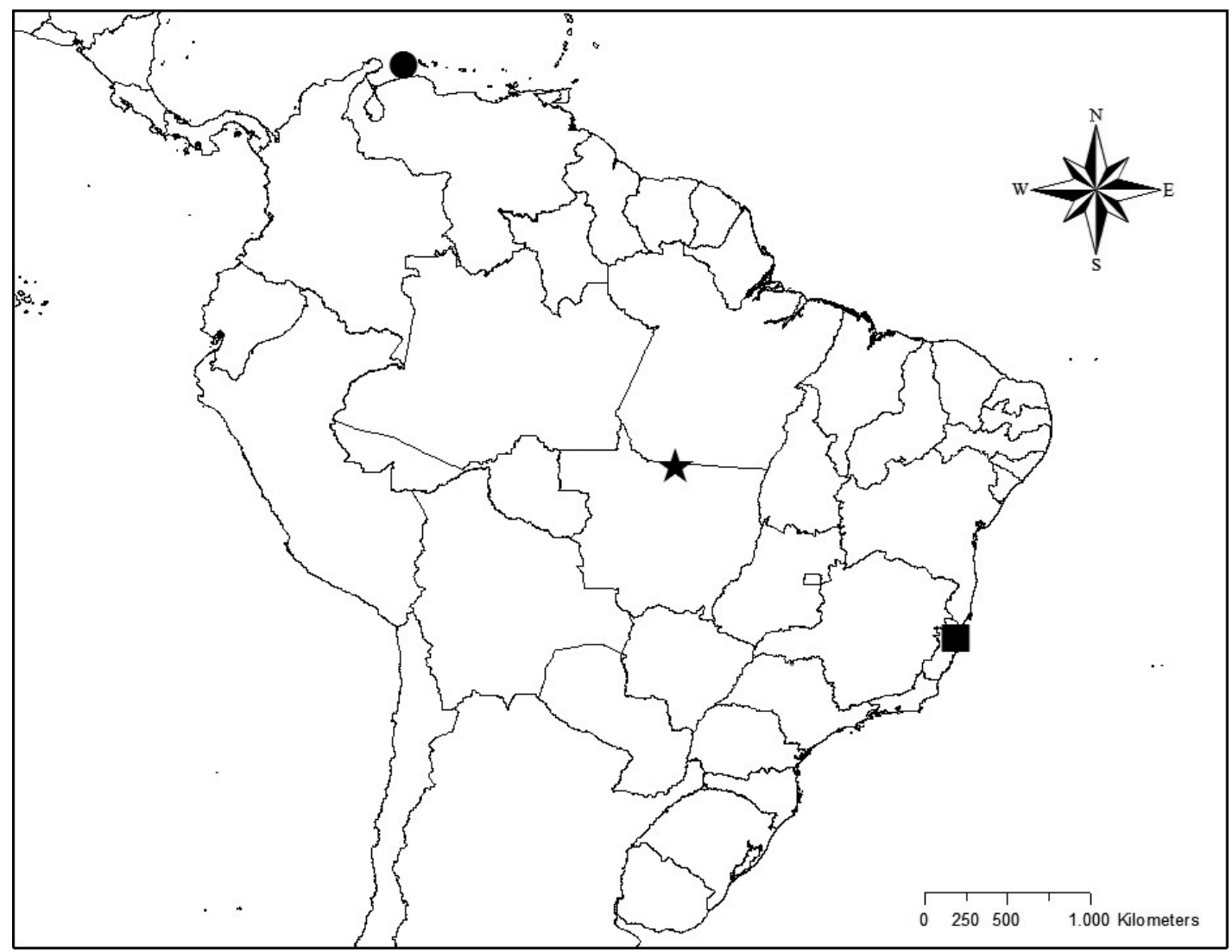

Figure 1. Location of new record of centipede predation in the Cristalino State Park, Novo Mundo, Mato Grosso, Brazil, indicated in the map by a solid star. The solid square indicates the register in the Atlantic Forest, Brazil and the solid circle indicates the register in Venezuela. 
a transition between tropical rainforest climate (Af) of the Amazon and the tropical wet climate (Aw). At Cristalino, a dry season occurs from May to September with a wet season from October to April. The annual mean precipitation and temperature are $2,400 \mathrm{~mm}$ and $24^{\circ} \mathrm{C}$, respectively.

On October $6^{\text {th }}, 2013$, predation by Scolopendra viridicornis on a Molossus molossus bat at the Cristalino State Park was recorded (Figure 2), close to the Central Administration building, a small wooden structure about three meters tall. As with Molinari et al. (2005) and SrbekAraujo et al. (2012) the observation was fortuitous. Prior to the predation event, the centipede was observed walking on the wooden wall, on which the bat was roosting alone, close to the ceiling. A few minutes later, at $4: 35 \mathrm{pm}$, the bat's distress call was heard. Examination showed the centipede had grabbed the bat. The centipede moved its body and head quickly, injecting venom via the forcipules into the bat's neck region and concomitantly grabbing the other part of the bat, namely thorax and abdomen, with its 15 pairs of anterior legs. The centipede was observed biting the bat repeatedly in the neck and in the abdominal region. While killing the bat, the centipede configured its body into an S-shape and, with its posterior pair of legs, attached itself to the roof (Figure 2). Both specimens were collected after 20 minutes of the observation. The centipede was identified using the specifc literature (Bücherl 1939; 1946a) and the bat with the key in Gregorin and Taddei (2002). The specimens are housed in the Acervo Biológico da Amazônia Meridional - ABAM in Sinop/Mato Grosso (S. viridicornis: ABAM-MYR 003; length: $150 \mathrm{~mm}$ and M. molossus ABAM-M 0001; forearm length: $35.79 \mathrm{~mm}$ ).

Bats are preyed upon by a wide range of vertebrate predators, but there are few records of invertebrate predators (Timm and Losilla 2007). They are commonly believed

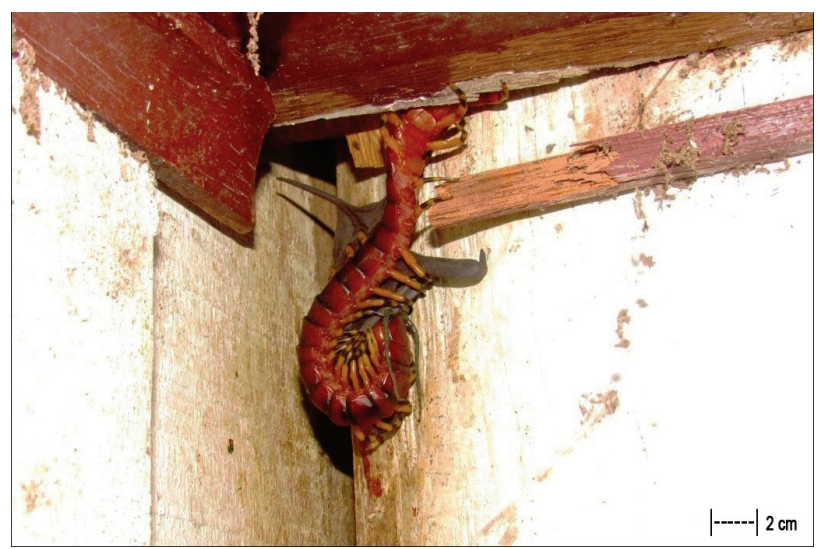

Figure 2. Predation by giant centipede (Scolopendra viridicornis) on bat (Molossus molossus) in the Amazon Forest, Cristalino State Park, Mato Grosso, Brazil. This figure is in color in the electronic version. to suffer lower predation rates than other mammals, but predation by invertebrates such as spiders (Timm and Losilla 2007; Nyffeler and Knörnschild 2013) and giant centipedes (Molinari et al. 2005; Srbek-Araujo et al. 2012) on small bats may be more common than previously recorded (Timm and Losilla 2007). Similar predatory behaviors, such as the ones described in this register, have been reported elsewhere (Cloudsley-Thompson 1968; Molinari et al. 2005; SrbekAraujo et al. 2012), where scolopendrids often inflict an initial puncture with their forcipules on the neck of vertebrate prey (Shugg 1961; Cloudsley-Thompson 1968). Venom injected near the brain quickly immobilizes the prey (Stankiewicz et al. 1999) due to the action of neurotoxins (Undheim and King 2011). Although the toxicity of centipede venom to bats is unknown (Molinari et al. 2005), it is enough to kill mice in 20-32 seconds (Bücherl 1946b).

These results suggest that vertebrates may be important prey for giant centipedes due to their nutritional composition, or quantity of nutrients offered per individual prey (Molinari et al. 2005). However, foraging behavior has an important role in the evolutionary biology and ecology of this group as it is a major determinant of survival, growth, and reproductive success (Kramer 2001) and it is necessary to perform studies on the consumption of vertebrates by invertebrates, especially centipedes.

\section{ACKNOWLEDGMENTS}

We would like to thank three anonymous reviewers for their constructive criticism and linguistic corrections of this manuscript. Enildes Neris Fernandes for identification of bat, Conselho Nacional de Desenvolvimento Científico e Tecnológico and Fundação de Amparo a Pesquisa de Mato Grosso for financial support.

\section{REFERENCES}

Bücherl, W. 1939. Os quilopodos do Brasil. Memorias do Instituto Butantan, 13: 43-362.

Bücherl, W. 1946a. Novidades sistematicas na ordem Scolopendromorpha. Memórias do Instituto Butantan, 19: $135-158$

Bücherl, W. 1946b. Ação do veneno dos escolopendromorfos do Brasil sobre alguns animais de laboratório. Memórias do Instituto Butantan, 19: 181-198.

Cloudsley-Thompson, J.L. 1968. Spiders, scorpions, centipedes and mites. Pergamon Press, Oxford, 1968, 278p.

Dugon, M.M.; Arthur, W. 2012a. Comparative studies on the structure and development of the venom-delivery system of centipedes, and a hypothesis on the origin of this evolutionary novelty. Evolution \& Development, 14: 128-137.

Dugon, M.M.; Arthur, W. 2012b. Prey orientation and the role of venom availability in the predatory behavior of the centipede 
Scolopendra subspinipes mutilans (Arthropoda: Chilopoda). Journal of Insect Physiology, 58: 874-880.

Forti, L.R.; Fischer, H.Z.; Encarnação, L.C. 2007. Treefrog Dendropsophus elegans (Wied-Neuwied, 1824) (Anura: Hylidae) as a meal to Otostigmus tibialis Brölemann, 1902 (Chilopoda: Scolopendridae) in the tropical rainforest in southeastern Brazil. Brazilian Journal of Biology, 67: 583-584.

Gregorin R.; Taddei V.A. 2002. Chave artificial para a identificação de Molossídeos brasileiros (Mammalia, Chiroptera). Mastozoología Neotropical, 9: 13-32.

Johnson, N.F.; Triplehorn, C.A. 2004. Borror and DeLong's Introduction to the Study of Insects. 7nd ed. Brooks Cole, Belmont, $864 \mathrm{p}$.

Köppen, W. 1936. Das geographisca System der Klimate. In: Köppen, W.; Geiger, G. (Ed.). Handbuch der Klimatologie 1. C.Gebr, Borntraeger, p. 1-44.

Kramer, D.L. 2001. Foraging behavior. In: Fox, C.W.; Roff, D.A.; Fairbairn, D.J. (Ed.). Evolutionary Ecology: Concepts and Case Studies. Oxford University Press, New York, p. 232-246

Malta, M.B.; Lira, M.S.; Soares, S.L.; Rocha, G.C.; Knysak, I.; Martins, R. et al. 2008. Toxic activities of Brazilian centipede venoms. Toxicon, 52: 255-263.

Molinari, J.; Gutiérrez, E.E.; Ascenção, A.A.; Nassar, J.M.; Arends, A.; Márquez, R.J. 2005. Predation by giant centipedes, Scolopendra gigantea, on three species of bats in a Venezuelan cave. Caribbean Journal of Science, 41: 340-346.

McCormick, S.; Polis, G.A. 1982. Arthropods that prey on vertebrates. Biological Review, 57: 29-58.

Menin, M.; Rodrigues, D.J.; Azevedo, C.S. 2005. Predation on amphibians by spiders (Arachnida, Aranae) in the Neotropical region. Phyllomedusa, 4: 39-47.
Nyffeler, M.; Knörnschild, M. 2013. Bat predation by spiders. PLoS ONE, 8: e58120.

Shugg, B. 1961. Predation on mouse by centipede. Western Australian Naturalist, 8:52.

Srbek-Araujo, A.C.; Nogueira, M.R.; Lima, I.P.; Peracchi, A.L. 2012. Predation by centipede Scolopendra viridicornis (Scolopendromorpha, Scolopendridae) on roof-roosting bats in the Atlantic Forest of southeastern Brazil. Chiroptera Neotropical, 18: 1128-1131.

Stankiewicz, M.; Hamon, A.; Benkhalifa, R.; Kadziela, W.; Hue, B.; Lucas, S. et al. 1999. Effects of a centipede venom fraction on insect nervous system, a native Xenopus oocyte receptor and on an expressed Drosophila muscarinic receptor. Toxicon, 10: 1431-1445.

Toledo, L.F. 2005. Predation of juvenile and adult anurans by invertebrates: current knowledge and perspective. Herpetological Review, 36: 395-400.

Timm, R.M.; Losilla, M. 2007. Orb-weaving spider, Argiope savignyi (Araneidae), predation on the Proboscis Bat Rhynchonycteris naso (Emballonuridae). Caribbean Journal of Science, 43: 282-284.

Undheim, E.A.B.; King, G.F. 2011. On the venom system of centipedes (Chilopoda), a neglected group of venomous animals. Toxicon, 57: 512-524.

Voigtländer, K. 2011. Chilopoda - Ecology. In: Minelli, A. (Ed.). The Myriapoda, vol. 1. Brill, Leiden, p.309-325.

Recebido em 18/10/2014

Aceito em 27/02/2015 